\title{
THE EFFECT OF GIVING BREASTFEEDING ON BABY'S NUTRITIONAL STATUS: A COMPARATIVE STUDY IN NORTH BUTON DISTRICT, INDONESIA
}

\author{
Tasnim Tasnim ${ }^{1}$, Susiatin ${ }^{2}$ \\ ${ }^{1,2}$ College of Health Sciences Mandala Waluya Kendari, Southeast Sulawesi, Indonesia. \\ Corresponding Author : Tasnim Tasnim \\ Email : tasnim349@gmail.com
}

\begin{abstract}
Background: Mother who giving exclusive breast feeding in North Buton District was less than others in Nourt Buton District. This study investigated the risk factors of giving exclusive breastfeeding and non-exclusive breastfeeding for 0-6 month old babies' nutritional status in Kulisusu primary health care in North Buton District.

Methods: This study was quantitative study which used a Case Control study design. Data analysis used independen t-test. This study recruited 82 mothers who had under 6 months old babies. This study was conducted in Kulisusu Primary Health Care area, in North Buton, Southeast Sulawesi province, Indonesia.

Result: The resuld found that there was significant differences of nutritional status between babies who gave exclusive breastfeeding and non-exclusive breastfeeding for 0-6 months old babies ( $\mathrm{p}$ value $=0,001<0,05$ ).

Conclusion: This study suggested for health workers and community health volunteers to give motivate for mothers in order to give exclusive breastfeeding for their babies aged under 6 months. The primary health care must promote about benefits of exclusive breastfeeding for babies' health and their growth.
\end{abstract}

Key words: Exclusive, Breastfeeding, Baby, Nutrition, Status 


\section{INTRODUCTION}

The presentage of giving breastfeeding tends to decreasing in Southeeast Sulawesi. In 2016, the precentage of mothers who gave breastfeeding was about 53,37\%, compared to $47.43 \%$ in 2017 (1). North Buton was one of districts which had less numbers of mothers who gave breastfeeding for the babies compared to other district such as Konawe $(66,67 \%)$, Kolaka $(61,10 \%)$, South Konawe $(61,87 \%)$, Bombana $(66,39 \%)$, and North Kolaka district $(67,62 \%)$. Some of sub-district in North Buton District still had low percentage of babies who were breastfeed by their mothers such as in Bone sub-district, namely about $40.58 \%$. Compared to other sub-districts in North Buton, such as Kulisusu sub-district which had high percentage of mothers who gave breastmilk (2).

As we know breast milk is one of good food for a baby. Adequate breastmilk for babies will help the baby's growth. Breast milk also can protect the baby from infectious disease because of increasing baby's immunity (3). Giving breastfeeding for the baby also can increase mother's health condotion. The mothers can prevent from breast cancer or Carcinoma mamae (4, 5). However, there are still mothers who do not give exclusive breast milk for less than six months old baby. There are many factors for that condition. One of the factor is social class and culture (5). Other factor is family support, and mothers' knowledge and attitude. Another factor is the brand of formula milk (5). Because of breastfeeding is very important for baby' nutrition and health status, so this study investigates the effect of breast milk compared to formula milk for baby's nutritional status. This study was taken in North Buton.

\section{METHOD}

The pupose of study is to understand the differences of babies' nutritional status between babies who were given breast milk compared to babies who were given formula milk. This quantitative study used cross sectional study design. This study was taken in Kulisusu Primary Health Care area in Kulisusu sub-district of North Buton district, Southeast Sulawesi in Indonesia. This study was conducted in May to August 2018. The study recruited 82 babies aged less than 6 months old and their mothers. The samples were obtained with simple random sampling technique. Data anlysis used independent samples t-test of statistical test. The significant effect used 0.05 .

\section{RESULT}

There were 82 babies who were investigated for four months. The distribution of age of the respondents is shown in this table.

Table 1. Distribution of baby's age in Kulisusu Primary Health Care Area, North Buton District in 2018

\begin{tabular}{ccc}
\hline $\begin{array}{c}\text { Age of Baby } \\
\text { (Month) }\end{array}$ & $\begin{array}{c}\text { Number } \\
(\mathbf{n})\end{array}$ & $\begin{array}{c}\text { Percentage } \\
(\mathbf{\%})\end{array}$ \\
\hline 1 & 9 & 11.0 \\
\hline 2 & 10 & 12.2 \\
\hline 3 & 8 & 9.8 \\
\hline 4 & 25 & 30.5 \\
\hline 5 & 18 & 22.0 \\
\hline 6 & 12 & 14.6 \\
\hline Total & 82 & 100 \\
\hline
\end{tabular}

The higher proportion of baby aged 4 months $(30.5 \%)$, while the lower propostion of baby aged 3 months (9.8\%). They comprised of male (42.7\%) and female babies $(57.3 \%)$ (Table 2 ).

Table 2. Distribution of sex of babies in The Study in 2018

\begin{tabular}{ccc}
\hline Sex & $\begin{array}{c}\text { Number } \\
(\mathbf{n})\end{array}$ & $\begin{array}{c}\text { Percentage } \\
(\boldsymbol{\%})\end{array}$ \\
\hline Male & 35 & 42,7 \\
\hline Female & 47 & 57,3 \\
\hline Total & 82 & 100 \\
\hline
\end{tabular}


Based on the mother's age, the high proportion of age was mothers aged between 26-30 years old, namely 39\% (32 mothers). The lowers proportion of mother's age was $36-40$ years old, namely 14 mothers $(17.1 \%$

Table 3. Distribution of mother's age in this study in 2018

\begin{tabular}{ccc}
\hline $\begin{array}{c}\text { Mother's } \\
\text { age }\end{array}$ & $\begin{array}{c}\text { Number } \\
(\mathbf{n})\end{array}$ & $\begin{array}{c}\text { Percentage } \\
(\boldsymbol{\%})\end{array}$ \\
\hline $20-25$ & 16 & 19,5 \\
\hline $26-30$ & 32 & 39,0 \\
\hline $31-35$ & 20 & 24,4 \\
\hline $36-40$ & 14 & 17,1 \\
\hline Total & 82 & 100 \\
\hline
\end{tabular}

Some of mothers passed from Senior high school, namely 52 mothers (63.4\%). The lower proportion of mothers had Yunior high school of their educational level, namely 12 mothers (14.6\%) (see table 4 ).
Table 4. Distribution of mother's educaational level in this study in 2018

\begin{tabular}{ccc}
\hline $\begin{array}{c}\text { Mother's } \\
\text { education }\end{array}$ & $\begin{array}{c}\text { Number } \\
(\mathbf{n})\end{array}$ & $\begin{array}{c}\text { Percentage } \\
(\mathbf{\%})\end{array}$ \\
\hline Bacheloor & 18 & 22,0 \\
\hline $\begin{array}{c}\text { Senior high } \\
\text { school }\end{array}$ & 52 & 63,4 \\
\hline $\begin{array}{c}\text { Yunior high } \\
\text { school }\end{array}$ & 12 & 14,6 \\
\hline Total & 82 & 100 \\
\hline
\end{tabular}

Some of the mother also did not have job $(61 \%)$. They were wives and do domestic chores. Howeve, there wer around 18 mothers who worked as civil serven (22\%) and taders (17.1) (table 5).

Based on the investigation, there was significant difference of babies' nutritional status between babies who were given breast milk and formula milk ( $\mathrm{p}$ value $=0.001<$ 0.05 .

Table 5. Distribution of Mother's Job in This Study in Kulisusu Subdistrict of North Buton District in 2018

\begin{tabular}{ccc}
\hline Mother's Job & Number (n) & Percentage (\%) \\
\hline No job & 50 & 61,0 \\
\hline Civil Serven & 18 & 22,0 \\
\hline Trader & 14 & 17,1 \\
\hline Total & 82 & 100 \\
\hline
\end{tabular}

Table 6. Comparation of Babies' Nutritional Status between Babies who were Given Breast Milk and Formula Milk in Kulisusu Sub-Distribusi in 2018

\begin{tabular}{ccccccc}
\hline \multirow{2}{*}{$\begin{array}{c}\text { Nutritional } \\
\text { Status }\end{array}$} & \multicolumn{2}{c}{ Formula Milk } & \multicolumn{2}{c}{ Breast Milk } & \multicolumn{2}{c}{ Total } \\
\cline { 2 - 7 } & $\mathbf{n}$ & $\boldsymbol{\%}$ & $\mathbf{n}$ & $\boldsymbol{\%}$ & $\mathbf{n}$ & $\%$ \\
\hline Good & 25 & 60,98 & 41 & 100 & 66 & 80,49 \\
\hline Worse & 16 & 39,02 & 0 & 0 & 16 & 19,51 \\
\hline Total & 41 & 100 & 41 & 100 & 82 & 100 \\
\hline
\end{tabular}


Table 7. Independent $t$ test of differences of babies' nutritional Status between babies who were given Breast milk and Formula Milk in Kulisusu Sub-District in 2018

\begin{tabular}{lcccc} 
Paired Differences & Mean & $\mathrm{t}$ & $\mathrm{df}$ & Sig. (2-tailed)* \\
& & & & \\
\hline $\begin{array}{l}\text { Nutritional Status }- \\
\text { Breast feeding }\end{array}$ & -0.305 & -3.536 & 81 & 0.001 \\
\hline
\end{tabular}

Note: *Independent sample t-test

\section{DISCUSSION}

The finding explains that breast milk gave significant effect for under 6 months old babies' nutritional status rather than formula milk. The babies who were given breast milk had good growth compared to those who were given formula milk. This finding shows that breast milk is one of good food for under 6 months old babies. The composision of nutrition in breast milk is still adequate for under 6 months old babies although they are not fed additional food. As we know that breast milk contains about $7 \%$ of carbohidrate, $0.9 \%$ of protein and $3.8 \%$ of fat (4). Compared to the formula milk compresses only $4.8 \%$ of carbohidrate, $3,4 \%$ of protein and $3.7 \%$ of fat. Therefore, under 6 months old babies do not need additional food. The breast milk is still enough for under-6 months old babies' nutrition needs (3). Some of others studies stated that under 6 months old bibies who were breastfed exclusively about 1.62 times bigger than those who were not given exclusive breastfeeding (6).

Adequate nutrition in under six months old babies is very important because the growth in this period will affect to whole individual health. Therefore, this period is called with the golden age (7). Moreover, breastfeeding has some benefits, including mother's psychology and family income. Interms of mother's psychology, breastfeeding can prevent or obstruct post parturition. Also, breastfeeding can prevent breast cancer and delay pragnancy (8).

By increasing mother's health status, babies will get good rearing from their health mother. Thus, the babies will growth and become new health and strong generation. The next generation will have high productivity which affect to their income and wellbeing. By increasing the family income, the national income also will increase which affect to high quality of public services. This means, community health and wellbeing will be secure. As we know that income is one of determinants of nutritional status in children, especially in under five years old $(9,10)$. Therefore, breastfeeding is very important aspect, especially for under six months old babies.

Moreover, as we understand from this finding that about $61 \%$ mothers in this study did not have job. This means the mothers had enough time to nurture their babies. The mothers could be able to prepare breast milk anytime. Compared to working mothers, the mothers did not have enough time to give breast milk, except there are a breastfeeding or nursery room in their office.

\section{CONCLUSION}

As above explanation, some of strategies should be done to motivate mothers in order to give breast milk rather than formula milk. First of all, health promotor in Kulisusu Primary Health Care 
give education or promotion about composision and benefit of breast milk for babies and the mothers. Inovation to take health promotion should be create and built by health workers. For example, health promotion can be conducted with community volunteers. Some of study about community volunteers states that they could help effectively health workers to enggage their neighboors towards healthy life or healthy behaviour $(11,12)$. The effective strategies in the health education or promotion to mothers especially can increase their nutritional knowledge. Improving mothers' knowledge about nutrition, expecially about breastfeeding can reduce prevalence in malnourished under five years old children (13). Furthermore, The government policy about nursery room must be implemented seriously. Implementation of this policy can increase the number of working mothers to give breast milk to their babies.

\section{REFERENCES}

1. Health Department in Southeast Sulawesi Province. Profile of health in Southeast Sulawesi Province in 2017. Kendari: Health Department in Southeast Sulawesi Province; 2018.

2. Health Department of North Buton. Health profile of North Buton District in 2017. Burunga: Health Department of North Buton; 2018.

3. World Health Organization. Global strategy for infant and young child feeding. Geneva: World Health Organization; 2003.

4. Pane HW, Tasnim T, Sulfianti, Hasnidar, Puspita R, Hastuti P, et al. Gizi dan Kesehatan. Medan: Yayasan Kita Menulis; 2020.

5. Victora CG, Bahl R, Barros AJD, França GVA, Horton S, Krasevec J, et al. Breastfeeding in the 21st century: epidemiology, mechanisms, and lifelong effect. The Lancet. 2016;387(10017):475-90.
6. Fitri DI, Chundrayetti E, Semiarty R. The relationship between giving breastmilk and growth in six months old babies in Naggalo Primary Health Care. Jurnal Kesehatan Andalas. 2014;3(2):136 - 9 .

7. Kertamuda MA. Golden age: the sucsessful strategy to build golden characters for early age children. Jakarta: PT. Elex Media Koputindo; 2015.

8. Suradi R. Biology specification of breastmilk. Sari Pediatri. 2001;3(3):125 - 9 .

9. Tasnim T. Determinants of malnutrition in children under five years in developing countries: A systematic review. Indian Journal of Public Health Research \& Development. 2018;9(6):333 - 8.

10. Abdalla MA, Sulieman SA, El Tinay AH, Khattab AGH. Socio-economic aspects influencing food consumption patterns among children under age of five in rural area of Sudan. Pakistan Journal of Nutrition. 2009;8(5):653-9.

11. Tasnim T, Lusida MI. The model of supervision for impermanent food sellers by women volunteer in Kendari City Indonesia. Indian Journal of Public Health Research \& Development. 2018;9(10):209-14.

12. Tasnim T. Community-led health planning model for village health team: A case study in Indonesia. Indonesian Journal of Health Sciences Research and Development. 2020;2(1):27-32.

13. Tasnim T, Mwanri L, Dasvarma G. Mother's child feeding knowledge and practices associated with underweight in children under-five years: A study from rural Konawe, Indonesia. Public Health of Indonesia. 2018;4(1):9-18. 